OPEN ACCESS

Edited by:

Kalpit V. Shah,

RMIT University, Australia

Reviewed by:

Fehmi Akgun,

TUBITAK Marmara Research Centre

Energy Institute, Turkey

S. M. Ashrafur Rahman,

Queensland University of Technology,

Australia

*Correspondence:

Norsyahida Mohammad

norsyahida.mohammad@uniten.edu.my

Specialty section:

This article was submitted to

Advanced Clean Fuel Technologies,

a section of the journa

Frontiers in Energy Research

Received: 02 November 2020 Accepted: 06 May 2021

Published: 24 May 2021

Citation:

Mohammad N, Mohamad Ishak WW, Mustapa SI and Ayodele BV (2021)

Natural Gas as a Key Alternative

Energy Source in Sustainable

Renewable Energy Transition: A

Mini Review.

Front. Energy Res. 9:625023.

doi: 10.3389/fenrg.2021.625023

\section{Natural Gas as a Key Alternative Energy Source in Sustainable Renewable Energy Transition: A Mini Review}

\author{
Norsyahida Mohammad ${ }^{*}$, Waznatol Widad Mohamad Ishak, Siti Indati Mustapa and \\ Bamidele Victor Ayodele
}

Institute of Energy Policy and Research, Universiti Tenaga Nasional, Kajang, Malaysia

Energy security and sustainability are undeniably the main concerns in combatting climate change. While an immediate call for all-green and renewable energy seems to be impossible due to huge financial implications and inadequate supporting energy structure, an alternative to fossil fuels needs to be established. Natural gas, a naturally occurring fossil gas is a cleaner energy source option compared to other fossil fuels such as coal, bitumen, and diesel. Natural gas makes the best fit for a sustainable renewable energy transition in any country around the globe due to its competitiveness towards other fossil fuels such as coal and its ability to aid the integration of renewables. This review highlights the technological pathways of utilizing natural gas in a transition to sustainable renewable energy systems, with a focus on the natural gas components and resources point of view for ASEAN member states (AMS). Policies that support the development of natural gas as a key alternative energy source in sustainable renewable energy transition would also be reviewed. This review aims to provide a thorough guide to researchers, stakeholders, and policymakers to construct and support efficient, reliable, affordable, sustainable, and environmentally friendly energy systems utilizing the abundant inexpensive natural gas.

Keywords: ASEAN, natural gas, energy transition, sustainable energy, alternative energy

\section{INTRODUCTION}

A sustainable energy transition is defined as a shift toward a high-efficiency energy system that is well-managed to balance environmental and social costs, risks, and benefits such that the shift is deemed to be sustainable (Chen et al., 2019). The transition also includes the shift from utilizing fossil fuel to exploiting renewable energy sources in energy generation and the evolution from centralized to decentralized energy systems (Guidolin and Alpcan, 2019). In Southeast Asia, coal-fired power plants are increasing due to the lower price of coal in the region, compared to oil and gas (Steckel et al., 2015). The use of coal for power generation contributes toward substantial greenhouse gas (GHG) emissions and deaths related to air pollution which include fine particulate matter emissions and toxic air contaminants (Kittner et al., 2018). However, immediate implementation of clean and renewable energy seems to be far-fetched due to the high capital costs and inadequate infrastructure in most ASEAN member states (AMS). A cleaner and more efficient fossil fuel such as natural gas 


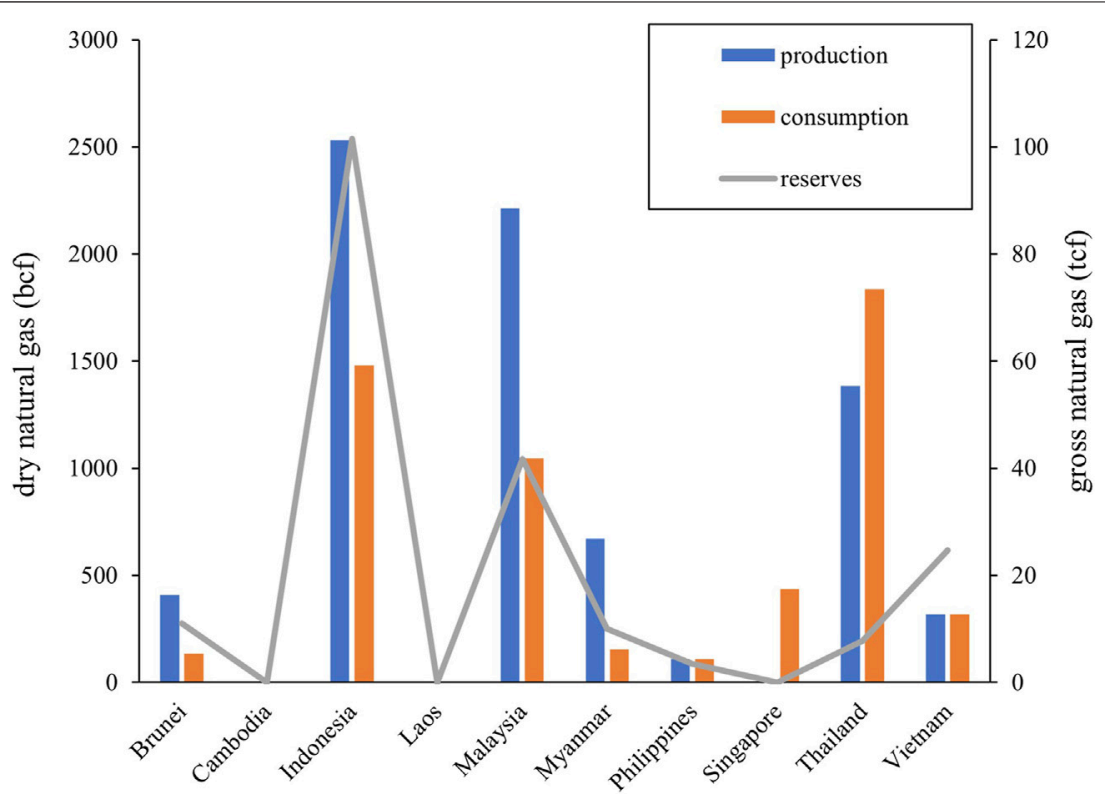

FIGURE 1 | The reserves, production, and consumption of natural gas in ASEAN countries in 2016.

could be utilized as an alternative energy source in bridging toward a sustainable renewable energy system in the ASEAN.

Natural gas consists of mainly methane gas, which emits the least amount of carbon dioxide $\left(\mathrm{CO}_{2}\right)$ and other harmful substances such as nitrogen oxides, sulfur dioxide, and particulates when combusted, compared to oil and coal. Direct replacement of coal with natural gas for power generation has proven to reduce GHG emissions tremendously (Mac Kinnon et al., 2018). The integration of natural gas and renewable energy resources in power generation ensures energy security and sustainability, while contributing toward a significant reduction of GHG toward a sustainable energy system, in line with the Paris Agreement adopted in 2015 (Denchak, 2018). The multi-lateral agreement aims to limit the global average temperature rise to below $2^{\circ} \mathrm{C}$, by reducing $\mathrm{GHG}$ emissions.

\section{NATURAL GAS RESERVES, PRODUCTION, AND DEMAND IN ASEAN}

As the ASEAN region is bestowed with an abundance of natural gas deposits, which put the region as a net natural gas exporter, it makes sense that natural gas is the key energy source for the sustainable renewable energy transition in the region. Malaysia, Indonesia, and Brunei are AMS that has been known as liquefied natural gas (LNG) exporter for the last four decades. Malaysia poses 42 trillion cubic feet (tcf) of proved natural gas reserves in 2016, which is the fifth-largest natural gas reserve holder in the Asia-Pacific region behind China, Indonesia, Australia, and India. According to Energy Information Administration (EIA), Malaysia is the third-largest exporter of LNG in the world after Qatar and Australia in 2016, and the second-largest oil and natural gas producer in Southeast Asia, behind Indonesia
(EIA, 2017). Indonesia, the most populous country in Southeast Asia, is the fifth-largest exporter of LNG in the world. Indonesia possessed 102 trillion cubic feet (tcf) of proved natural gas reserves in 2016. The country's proved natural gas reserves are the second largest in the Asia-Pacific region, after China. Brunei, the smallest country in ASEAN, produced 410 billion cubic feet of dry natural gas in 2016 and has been a long-term LNG exporter to Japan and Korea. The comparison of the reserves, production, and consumption of natural gas in ASEAN countries in 2016, based on data from EIA is depicted in Figure 1.

According to the ASEAN Centre for Energy (ACE), natural gas makes up to $24 \%$ of the ASEAN energy mix in 2016 (Silitonga and Anugrah, 2015). Natural gas is mainly utilized for power generation with more than one-third of the total installed power generation capacity in AMS (Silitonga and Anugrah, 2015). According to a report by IRENA in 2018, natural gas contributed the largest share $(41 \%)$ to the power generation mix for ASEAN in 2015, followed by coal (33\%) and hydropower (16\%) (IRENA, 2018). Three AMS that are Brunei, Singapore, and Thailand generate more than $70 \%$ of electricity from natural gas. However, under a business-asusual scenario, coal is expected to replace natural gas as the dominant source of power generation in the region by 2040 (IRENA, 2018).

Apart from utilizing natural gas as an export commodity and power generation, a smaller portion of natural gas is also utilized domestically for transportation and feedstock in industrial processes producing methanol, fertilizers, and pharmaceutical products. Compressed natural gas (CNG) is used in natural gas vehicles $(\mathrm{NGV})$ due to its lower price compared to petrol or diesel, and growing concern for the environment (Yusaf et al., 2001). Although most developed countries such as the United States, Canada, Europe, Australia, and New Zealand 
have been encouraging the use of NGV, in AMS however, the development and use of NGVs is relatively slow.

\section{AN OVERVIEW OF SYNTHETIC NATURAL GAS PRODUCTION METHODS}

There are three main pathways to produce synthetic natural gas (SNG) that are the biochemical, thermochemical, and electrochemical pathways (Fendt et al., 2016). The most common method of producing SNG would be the thermochemical method, where conventional non-renewable source, coal undergo the multi-step process to produce natural gas starting with gasification to produce mainly $\mathrm{CO}$ and $\mathrm{H}_{2}$, also known as the producer gas. The gas produced would undergo a scrubbing step to remove unwanted waste products, producing a pure mixture of $\mathrm{H}_{2}, \mathrm{CO}$, and $\mathrm{CO}_{2}$ termed as the synthesis gas. The synthesis gas then undergoes a water-gas shift reaction, followed by the methanation process to produce SNG. The methanation process requires catalysts from a range of transition metals dispersed on metal oxide supports such as $\mathrm{Ni} / \mathrm{Al}_{2} \mathrm{O}_{3}$ ( $\mathrm{Li}$ et al., 2013), $\mathrm{Ni} / \mathrm{TiO}_{2}$ (Shinde and Madras, 2014), Ni/a- $\mathrm{Al}_{2} \mathrm{O}_{3}$ (Gao et al., 2013), and $\mathrm{NiO}-\mathrm{CeO}_{2}$ (Atzori et al., 2018). A full review on methanation catalysts advancements for SNG production could be found in (Gao et al., 2015). The most common reactor type used in the methanation process is the fixed bed reactor due to its simple and effective design, although several other designs such as the fluidized bed reactor, honeycomb reactor, and microchannel reactor were also considered due to better catalyst exposure (Bolt et al., 2020).

Renewable sources such as dry biomass or solid waste obtained from municipal and agricultural wastes could be converted to SNG using the thermochemical pathway like coal. In the biochemical pathway, wet biomass undergoes fermentation to produce biogas, which is high in methane and $\mathrm{CO}_{2}$. After $\mathrm{CO}_{2}$ separation, the resulting gas could be fed directly into the natural gas grid. Another pathway for SNG production is the electrochemical pathway where the electricity generated from renewables was used to produce $\mathrm{H}_{2}$ via electrolysis, followed by methanation to produce SNG. Comprehensive reviews on SNG production methods could be found elsewhere (Kopyscinski et al., 2010; Fendt et al., 2016; Bolt et al., 2020).

\section{ROLE OF NATURAL GAS IN THE SUSTAINABLE RENEWABLE ENERGY TRANSITION}

Natural gas plays a major role in the short- to mid-term transition toward sustainable energy systems. Besides being a cleaner and more efficient fossil fuel than coal, natural gas is highly flexible such that natural gas peaking combustion turbines has a dynamic ramping ability that can increase or decrease electricity generation within less than an hour, allowing it to respond rapidly to fluctuations on the demand side and adjust to fluctuating power produced from inconsistencies of renewable energy resources such as solar and wind (Huang et al., 2019). In
Thailand, heavy reliance on natural gas for electricity generation enables the country to integrate utility-scale solar onto its flexible power grid. Thailand owns the highest share of utility-scale solar compared with other AMS (Tongsopit et al., 2015). Similarly, heavy reliance on natural gas for electricity generation in Brunei and Singapore enables future investments in offshore wind power generation. This boosts the potential of Brunei and Singapore in becoming flexible trading hubs for electricity and gas infrastructure (Huang et al., 2019). Besides, the existing natural gas supporting infrastructure which includes storage, transportation, and distribution can facilitate the integration of gaseous types of renewable fuels such as biogases. This enables the transition to fully utilize renewable energy for power generation in the future.

\section{AN OVERVIEW OF NATURAL GAS UTILIZATION FOR POWER GENERATION}

One of the main environmental concerns of natural gas power generation is that it produces significant amounts of $\mathrm{CO}_{2}$. However, the $\mathrm{CO}_{2}$ emission could be reduced by substituting conventional natural gas combustion turbines with state-of-theart advanced natural gas power generation technologies such as natural gas combined cycle plants, fuel cells, micro-turbines, and hybrid fuel cell/heat engine plants (Mac Kinnon et al., 2018). The advanced natural gas conversion technologies, in combination with low carbon and renewable energy in power generation, as well as the technology for carbon capture and storage (CCS) will be able to further reduce $\mathrm{CO}_{2}$ emission. The main principles of the CCS technologies to reduce $\mathrm{CO}_{2}$ emissions include precombustion capture, post-combustion capture, oxyfuel $\mathrm{O}_{2} / \mathrm{CO}_{2}$ recycle combustion capture, and chemical looping. However, the implementation of CCS technologies is limited due to unclear social and political acceptability (Bui et al., 2018).

Other technologies to capture $\mathrm{CO}_{2}$ from natural gas before input to power generation include chemical looping and hightemperature membranes. Besides, natural gas electricity generation could be integrated with renewable energy sources such as solar and wind, to further reduce $\mathrm{CO}_{2}$ emissions. Hydrogen could be produced by natural gas steam reforming and used to produce electricity. A system integrating hydrogen produced from natural gas combined with CCS has been proposed (Khan et al., 2020). The pathways for sustainable natural gas utilization in electricity generation are presented in Figure 2.

\section{LIFE CYCLE ANALYSIS ON NATURAL GAS USE FOR A SUSTAINABLE RENEWABLE ENERGY TRANSITION}

There are several life cycle analyses (LCAs) conducted on electricity generation from natural gas and its renewable energy alternatives including potential renewables for ASEAN which are solar, biomass, and wind. Although most LCA conducted used GHG emission as the main indicator for the 


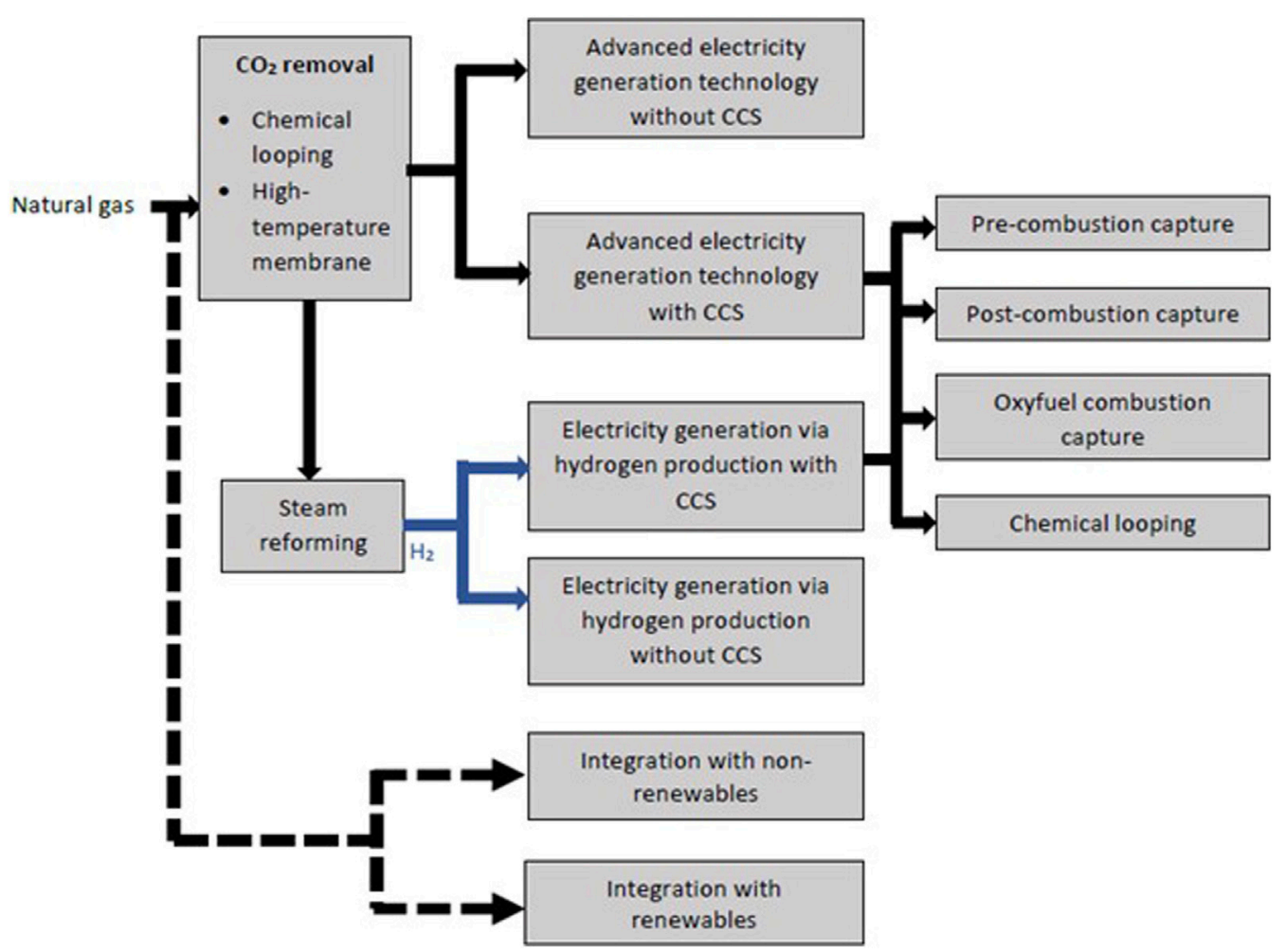

FIGURE 2 | Pathways for sustainable natural gas utilization for electricity generation.

environmental performance of a system, there are inevitably more factors that could be compared such as energy pay-back time, lifetime, and land use. Three LCA phases that need to be considered are fuel provision, plant operation, and infrastructure, although intricate details such as energy recovery efficiency, electricity mix utilized during construction, and quality of feedstocks contribute toward the variability of LCAs conducted (Turconi et al., 2013). It was found that the highest percentage of emissions came from plant operation for fossil fuelbased electricity generation such as power generation from natural gas, whereas in biomass-based power systems fuel provision produced the highest percentage of emissions (Turconi et al., 2013). GHG emissions in biomass-only electricity generation are highest when using wastes as feedstock, compared to using agriculture residues, dedicated crops, forestry, and industrial wastes (Kadiyala, 2016). It was also found that emissions from infrastructures remained the largest percentage in other renewables-based power generation systems such as systems driven by hydropower, solar, and wind (Turconi et al., 2013).

The GHG emission of a natural gas power plant ranges from 380 to $1,000 \mathrm{CO}_{2}$-eq, compared to its renewable alternatives such as solar (13-190 $\mathrm{CO}_{2}$-eq), biomass (8.5-130 $\mathrm{CO}_{2}$-eq), and wind (3-41 $\mathrm{CO}_{2}$-eq), based on the electricity outputs (Turconi et al., 2013). The LCA serves as a guideline on the cost-competitiveness and emissions of electricity generation using natural gas and its alternatives. However, the LCA conducted for the various electricity generation technologies provides differing judgements on environmental impacts due to different bases and indicators used in the assessments.

\section{NATURAL GAS INFRASTRUCTURE AND RENEWABLE ENERGY POLICIES IN ASEAN}

The Trans-ASEAN Gas Pipeline (TAGP) project and the ASEAN Power Grid (APG) have been established to enhance regional cooperation between the AMS and other countries outside the region, in meeting natural gas demands and ensuring energy security and sustainability within the region. The TAGP project aims to enhance connectivity between AMS to ensure energy security, flexibility, and accessibility via pipelines and regasification terminals producing approximately 17.8 million tonnes per annum (MTPA) natural gas (ACE, 2015). The TAGP project does not only provide natural gas for electricity generation but also provides natural gas for feedstock in heating and cooling systems for industries and municipal users. The APG enables the incorporation of a larger and more diverse pool of renewable energy resources from AMS, reducing dependence on the region's natural gas reserves. The electricity output from the multiple-resources integrated power system is also smoother as the individual renewable energy generating plants are accumulated over larger geographic areas (IEA, 2019). The establishment of the transnational supergrid would enhance economic growth and development within the region, meeting the growing electricity demand, and producing a resilient electricity infrastructure within the region. 
The price-competitiveness of natural gas produced by AMS is indeed a big determinant for ensuring sustainable utilization of natural gas in this region. Increasing reliance on imports makes natural gas less price-competitive (IEA, 2019). Economic challenges in sustainable utilization of natural gas include capital intensity, financing, and returns on investment of the natural gas pipelines and LNG projects within the region (Sovacool, 2009). It is important to seek cost-optimal pathways for sustainable natural gas utilization, which includes electricity generation, transmission, and storage to maintain robust economic growth within the region.

The existing policy frameworks need to be expanded to support natural gas as a mediator for the integration of renewable energy into the grid. Most AMS have put forward policies and targets of integrating renewable energy into their energy mix. Brunei, an oil-rich AMS has put forward plans to generate $10 \%$ of power from renewables by 2035 , while Indonesia has set a target of $31 \%$ of renewable energy in its energy mix by 2050 (IRENA, 2018). Moreover, energy efficiency targets, renewable energy policies, and institutional frameworks on renewable energy resources have been put in place to enhance the integration of renewable energy in the energy mix of the AMS. A detailed discussion on energy and renewable energy policies in ASEAN could be found elsewhere (Lidula et al., 2007). Various instruments on renewable energy such as feed-in-tariff, capital subsidies, permits, tax incentives, and renewable portfolio standards have been introduced in AMS to achieve its targeted $23 \%$ renewable energy share at the regional level by 2025 (Erdiwansyah, 2019). However, the implementation of the existing policies is yet to achieve a satisfactory level of effectiveness due to barriers such as high capital of renewable energy installation, inadequate investments, and lack of technology and knowledge transfer (Chang, 2015).

\section{CONCLUSION AND FUTURE RECOMMENDATIONS}

The abundance of natural gas in the ASEAN region indicates the suitability of natural gas as the key energy source for the transition toward short- and medium-term sustainable

\section{REFERENCES}

ACE (2015). “ASEAN Member States. Indonesia," in Asean Plan of Action for Energy Cooperation (APAEC) 2016-2025 Phase I: 2016-2020. Editor Christopher G. Zamora (Jakarta, Indonesia: ASEAN Centre for Energy).

Atzori, L., Cutrufello, M. G., Meloni, D., Cannas, C., Gazzoli, D., Monaci, R., et al. (2018). Highly Active NiO-CeO2 Catalysts for Synthetic Natural Gas Production by CO2 Methanation. Catal. Today 299, 183-192. doi:10.1016/j.cattod.2017.05.065

Bolt, A., Dincer, I., and Agelin-Chaab, M. (2020). A Critical Review of Synthetic Natural Gas Production Techniques and Technologies. J. Nat. Gas Sci. Eng. 84, 103670. doi:10.1016/j.jngse.2020.103670

Bui, M., Adjiman, C. S., Bardow, A., Anthony, E. J., Boston, A., Brown, S., et al. (2018). Andy Boston, Solomon Brown, Paul S Fennell, Sabine Fuss, Amparo Galindo, and Leigh A Hackett.Carbon Capture and Storage (CCS): the Way Forward. Energy Environ. Sci. 11 (5), 1062-1176. doi:10.1039/c7ee02342a renewable energy transition. Besides, natural gas could be produced via various methods utilizing renewable energy resources. The flexibility of power systems utilizing natural gas enables the integration of intermittent renewable energy such as solar and wind. The $\mathrm{CO}_{2}$ emissions resulted from natural gas power generation could be reduced via advanced natural gas conversion technologies, integration with renewables, and CCS technologies. The establishment of an ASEAN-integrated natural gas pipeline and power system can ensure sustainable utilization of natural gas. A comprehensive techno-economic analysis on advanced natural gas power generation integrated with CCS and renewables is crucial to assist transition toward sustainable renewable energy transition. Natural gas as a transition fuel in attaining sustainable renewable energy transition should be further evaluated based on four pillars namely availability, applicability, acceptability, and affordability. Renewable energy targets, natural gas policies, and related frameworks should be enhanced to support the utilization and development of natural gas as the alternative energy source in transitioning toward a sustainable energy system in AMS.

\section{AUTHOR CONTRIBUTIONS}

Conceptualization, $\mathrm{SM}$ and $\mathrm{BA}$; literature review and resources, $\mathrm{NM}$ and WM, writing, NM, review and editing, BA, funding acquisition, SM. All authors have read and agree to the published version of the manuscript.

\section{FUNDING}

This research was supported by the Innovation and Research Management Centre (iRMC), Universiti Tenaga Nasional.

\section{ACKNOWLEDGMENTS}

The authors acknowledge the financial support of iRMC, Universiti Tenaga Nasional.

Chang, Y., and Li, L. (2015). Renewable energy and policy options in an integrated ASEAN electricity market: Quantitative assessments and policy implications. Energy Policy 85, 39-49. doi:10.1029/2008GM000822

Chen, B., Xiong, R., Li, H., Sun, Q., and Yang, J. (2019). Pathways for Sustainable Energy Transition. J. Clean. Prod. 228, 1564-1571. doi:10.1016/j.jclepro.2019.04.372

Denchak, M. (2018). Paris Climate Agreement: Everything You Need to Know. (New York: Natural Resources Defense Council). https://www.nrdc.org/stories/ paris-climate-agreement-everything-you-need-know.

EIA (2017). Country Analysis Brief: Malaysia. U.S. Energy Information Administration. https://www.eia.gov/international/analysis/country/MYS.

Erdiwansyah, M., Mamat, R., Sani, M. S. M., Khoerunnisa, F., and Kadarohman, A. (2019). Target and demand for renewable energy across 10 ASEAN countries by 2040. The Electricity Journal 32 (10), 106670. doi:10.1016/j.tej.2019.106670

Fendt, S., Buttler, A., Gaderer, M., and Spliethoff, H. (2016). Comparison of Synthetic Natural Gas Production Pathways for the Storage of Renewable Energy. Wires Energ. Environ. 5 (3), 327-350. doi:10.1002/wene.189 
Gao, J., Jia, C., Zhang, M., Gu, F., Xu, G., and Su, F. (2013). Effect of Nickel Nanoparticle Size in Ni/a-Al2O3 on $\mathrm{CO}$ Methanation Reaction for the Production of Synthetic Natural Gas. Catal. Sci. Technol. 3 (8), 2009-2015. doi:10.1039/c3cy00139c

Gao, J., Liu, Q., Gu, F., Liu, B., Zhong, Z., and Su, F. (2015). Recent Advances in Methanation Catalysts for the Production of Synthetic Natural Gas. RSC Adv. 5 (29), 22759-22776. doi:10.1039/C4RA16114A

Guidolin, M., and Alpcan, T. (2019). Transition to Sustainable Energy Generation in Australia: Interplay between Coal, Gas and Renewables. Renew. Energ. 139, 359-367. doi:10.1016/j.renene.2019.02.045

Huang, Y. W., Kittner, N., and Kammen, D. M. (2019). ASEAN Grid Flexibility: Preparedness for Grid Integration of Renewable Energy. Energy Policy 128, 711-726. doi:10.1016/j.enpol.2019.01.025

IEA (2019). Southeast Asia Energy Outlook 2019. Paris: International Energy Agencyhttps://www.iea.org/reports/southeast-asia-energy-outlook-2019.

IRENA (2018). Renewable Energy Market Analysis: Southeast Asia. Abu Dhabi: International Renewable Energy Agency

Kadiyala, A., Kommalapati, R., and Huque, Z. (2016). Evaluation of the Life Cycle Greenhouse Gas Emissions from Different Biomass Feedstock Electricity Generation Systems. Sustainability 8 (11), 1181

Khan, M. N., Cloete, S., and Amini, S. (2020). Efficient Production of Clean Power and Hydrogen through Synergistic Integration of Chemical Looping Combustion and Reforming. Energies 13 (13), 3443. doi:10.3390/ en 13133443

Kittner, N., Fadadu, R. P., Buckley, H. L., Schwarzman, M. R., and Kammen, D. M. (2018). Trace Metal Content of Coal Exacerbates Air-Pollution-Related Health Risks: The Case of Lignite Coal in Kosovo. Environ. Sci. Technol. 52 (4), 2359-2367. doi:10.1021/acs.est.7b04254

Kopyscinski, J., Schildhauer, T. J., and Biollaz, S. M. A. (2010). Production of Synthetic Natural Gas (SNG) from Coal and Dry Biomass - A Technology Review from 1950 to 2009. Fuel 89 (8), 1763-1783. doi:10.1016/j.fuel.2010. 01.027

Li, J., Zhou, L., Li, P., Zhu, Q., Gao, J., Gu, F., et al. (2013). Enhanced Fluidized Bed Methanation over a Ni/Al2O3 Catalyst for Production of Synthetic Natural Gas. Chem. Eng. J. 219, 183-189. doi:10.1016/j.cej.2013.01.005

Lidula, N. W. A., Mithulananthan, N., Ongsakul, W., Widjaya, C., and Henson, R. (2007). ASEAN towards Clean and Sustainable Energy: Potentials, Utilization and Barriers. Renew. Energ. 32 (9), 1441-1452. doi:10.1016/j.renene.2006. 07.007

Mac Kinnon, M. A., Brouwer, J., and Samuelsen, S. (2018). The Role of Natural Gas and its Infrastructure in Mitigating Greenhouse Gas Emissions, Improving Regional Air Quality, and Renewable Resource Integration. Prog. Energ. Combustion Sci. 64, 62-92. doi:10.1016/j.pecs.2017.10.002

Shinde, V. M., and Madras, G. (2014). CO Methanation toward the Production of Synthetic Natural Gas over Highly Active Ni/TiO2catalyst. Aiche J. 60 (3), 1027-1035. doi:10.1002/aic.14304

Silitonga, R. J. P., and Anugrah, P. (2015). The Role of Natural Gas in ASEAN Energy Security. https://aseanenergy.org/the-role-of-natural-gas-in-aseanenergy-security/. (Jakarta, Indonesia: ASEAN Centre for Energy (ACE)).

Sovacool, B. K. (2009). Energy Policy and Cooperation in Southeast Asia: The History, Challenges, and Implications of the Trans-ASEAN Gas Pipeline (TAGP) Network. Energy Policy 37 (6):2356-2367. doi:10.1016/j.enpol.2009.02.014

Steckel, J. C., Edenhofer, O., and Jakob, M. (2015). Drivers for the Renaissance of Coal. Proc. Natl. Acad. Sci. USA 112, E3775-E3781. doi:10.1073/pnas.1422722112

Tongsopit, S., Chaitusaney, S., Limmanee, A., Kittner, N., and Hoontrakul, P. (2015). Scaling up Solar PV: A Roadmap for Thailand. Energy Research Institute, Chulalongkorn University

Turconi, R., Boldrin, A., and Astrup, T. (2013). Life Cycle Assessment (LCA) of Electricity Generation Technologies: Overview, Comparability and Limitations. Renew. Sustainable Energ. Rev. 28, 555-565. doi:10.1016/j.rser.2013.08.013

Yusaf, T. F., Salleh, H., Lai, T. Y., and Ramesh, S. (2001). Economic Aspect of Natural Gas Vehicle in Malaysia. J. Ind. Technol. SIRIM, Malaysia 10, 25-36.

Conflict of Interest: The authors declare that the research was conducted in the absence of any commercial or financial relationships that could be construed as a potential conflict of interest.

Copyright (c) 2021 Mohammad, Mohamad Ishak, Mustapa and Ayodele. This is an open-access article distributed under the terms of the Creative Commons Attribution License (CC BY). The use, distribution or reproduction in other forums is permitted, provided the original author(s) and the copyright owner(s) are credited and that the original publication in this journal is cited, in accordance with accepted academic practice. No use, distribution or reproduction is permitted which does not comply with these terms. 